This item was submitted to Loughborough's Research Repository by the author.

Items in Figshare are protected by copyright, with all rights reserved, unless otherwise indicated.

\title{
Unveiling the biographies of media: on the role of narratives, anecdotes and storytelling in the construction of new media's histories
}

PLEASE CITE THE PUBLISHED VERSION

http://dx.doi.org/10.1111/comt.12099

PUBLISHER

(c) Wiley

VERSION

AM (Accepted Manuscript)

\section{PUBLISHER STATEMENT}

This work is made available according to the conditions of the Creative Commons Attribution-NonCommercialNoDerivatives 4.0 International (CC BY-NC-ND 4.0) licence. Full details of this licence are available at: https://creativecommons.org/licenses/by-nc-nd/4.0/

\section{LICENCE}

CC BY-NC-ND 4.0

\section{REPOSITORY RECORD}

Natale, Simone. 2019. "Unveiling the Biographies of Media: On the Role of Narratives, Anecdotes and Storytelling in the Construction of New Media's Histories". figshare. https://hdl.handle.net/2134/20050. 


\title{
Unveiling the Biographies of Media: On the Role of Narratives, Anecdotes and Storytelling in the Construction of New Media's Histories
}

Accepted version

Simone Natale, Loughborough University

\begin{abstract}
The article proposes the notion of "biographies of media" to address the complex ways through which media change is the subject of narration and storytelling. This concept provides theoretical tools to unveil how different narratives contribute to shape media's identities and to carry particular representations of their roles in our society and everyday life. Relying on theoretical approaches to storytelling and to the biographical genre, as well as on a range of examples from media history, the article shows that narratives are not only key elements in the content of media texts, but also ways through which the impact of media on society and everyday life is represented and negotiated within the public sphere.
\end{abstract}

\section{Keywords}

Media and storytelling; media narratives; media history; media and the imaginary; media and everyday life; social life of things. 


\section{Unveiling the Biographies of Media: On the Role of Narratives, Anecdotes and Storytelling in the Construction of New Media's Histories}

As social anthropologists such as Armin Appadurai and Alfred Gell have taught us, not only humans, but also artifacts can be regarded as social agents (Appadurai, 1986; Gell, 1998). In Gell's own words, "social agency can be exercised relative to 'things' and social agency can be exercised by 'things' (and also animals)" (Gell, 1998, pp. 17-18); therefore, artifacts can appear as agents in particular social situations. It is for this reason that people often attribute intentions to objects and machines: car owners, for instance, may attribute personality to their cars, and a girl may attribute personality to her doll. Things, like people, have social lives, and their meaning is continually negotiated within a process that informs technological changes as well as the way they are inserted within social relations (Edwards, 2002). Working within the same framework, Igor Kopytoff argues that things have their own biographies, too, according to which their status and reception is established within different societies and culture. Reconstructing the circumstance of creations of these biographies, he notes, "can make salient what might otherwise remain obscure” (Kopytoff, 1986, p. 67). ${ }^{1}$

Following from this body of scholarship, this article proposes that the notion of biography should be employed in the analysis of a particular kind of "objects": media technologies -defined, in the broader sense of this term, as aggregates of communication systems, technologies, platforms, institutions, and users (Carey, 1989; Flichy, 1995). Similarly to the artifacts to which Gell and Appadurai refer in their works, in fact, also media are depicted as agents in numerous social situations (Reeves \& Nass, 1996). Their biographies contribute to 
shape their identities and to carry particular representations of their roles in our society and everyday life. Authors such as Kopytoff use the notion of biography particularly to emphasize the changing material, cultural, and social nature of objects upon which biographical trajectories are inscribed throughout time. In regard with media, a similar perspective has been recently developed by Frederic Lesage (2013, 2016), who responded to earlier calls for employing a biographic approach in ethnographic studies of the domestication of media in everyday life (Silverstone \& Haddon, 1996). My own use of the concept, however, aims to stress the narrative character of biographical recounting. Biographies, in fact, are first and foremost a form of contingent narrative, a story that turns historical characters, places, events, and things into narratives that can be written, recounted, and circulated through numerous channels and in different ways (Caine, 2010, p. 124). In their most widespread sense, biographies are stories about the lifespans of individuals, who may or may not be prominent people. Yet, these stories entail something more than this: the lives of individuals come to signify other things. They have been employed throughout history to convey particular characterizations of political, ideological, and moral issues, supported by the instance of a notable or exemplary life (Furbank, 2000). Proposing the notion of biographies of media, therefore, functions as a call to examine how narratives about media move beyond the medium whose history they describe, to convey meanings about change, the relationship between the present, the past and the future, and the role of technology in societies and the world (see also Natale, 2012a, pp. 6-8).

Relying on theoretical approaches to storytelling and to the biographical genre, as well as on a range of examples from media history, the article shows that narratives are not only key elements in the content of media texts, but also ways through which the impact of media on society and everyday life is represented and negotiated within the public sphere. The first section 
introduces the notion of biographies of media, framing it within broader theoretical frameworks in media studies and history of technology. The second section focuses on the narrative nature of biographies of media, interrogating its implications in dialogue with scholarship on biographies, narrative, and storytelling. Stressing how established narratives allow people to make sense of new experiences and events, the section also shows that biographies of media are not just "stories"; they have an important impact on our reality and everyday life. The impact of biographies of media is further explored in the third section, which examines how they provide people with cognitive tools to cope with the transformations triggered by media change, and how they are employed by individuals and social groups to support economic, social, political and ideological agenda. Finally, the fourth section gives emphasis to the problem of authenticity. Biographies of media, in fact, may be constructed with reference to events that did or did not take place. The inaccuracy and fabrication of some of these stories, however, should not lead the gaze of researchers away from studying them and from locating them within broader biographies of media.

Throughout the text, I point to three fundamental elements in the biographies of media: storytelling, narratives, and anecdotes. While these words are interrelated and to a certain extent they overlap with each other, there are some subtle but important differences in their meanings. The word 'storytelling' refers to the human capacity and habit of forcing events, people and things into the fabric of a story. 'Narrative', in contrast, indicates not a skill or an act, but rather the story itself, with its forms and internal patterns. While using the notion of storytelling points to the agency and the inherent sociality of this act, narrative in contrast objectifies it, shedding light to its semiotic nature. Finally, 'anecdotes' are a specific form of narrative that relates an event of an interesting or entertaining nature. Looking at how anecdotes emerge and circulate 
helps to unveil the traditional and repetitive configurations through which the act of storytelling is performed.

\section{Defining the Biographies of Media: Technology, Imagination, Storytelling}

Increasingly since the nineteenth century, as new technologies have been introduced and new modalities of spectatorship and interaction emerged, people also developed particular ways of talking about media and their relationship to them. Some of these ways have been particularly persistent, turning into recurring narrative patterns that shaped the conceptual and imaginative frameworks we use to understand media. In media and cultural studies, a rising literature addressing the relationship between media and the imagination has emerged, pointing to the fact that media are not only machines, artifacts, and social systems, but also imaginary and cultural constructs that contribute to shape our understanding of broader cultural issues, and create new ways to narrate and make sense of the transformations experienced in our society and everyday life (Natale \& Balbi, 2014). This approach finds its roots in the works of scholars in American studies, such as Leo Marx (1964), James Carey (1989), and David Nye (1994), who employed the notion of "technological sublime" to address how technologies (including media) stimulate the formation of myths and imaginary constructions within the public sphere. More recently, this tradition has been revitalized by media scholars who examined the representation of novelty and newness in regard with mediated technology (Gitelman, 2006; Marvin, 1988), by the supporters of media archaeology as a perspective merging the discursive and the material nature of media (Huhtamo, 1997; Kluitenberg, 2006), as well as by scholars in new media studies who tackled the emergence of myths and imaginations regarding digital technologies (Flichy, 2007; Mosco, 2004). 
Yet, in this contexts, the particular role played in this context by narrative and storytelling has been the subject, until now, of scarce attention. Notable exceptions include works that underlined the possibility of media existing at a purely discursive level (Huhtamo, 2013; Kluitenberg, 2006; Thibault, 2013), showed the influence in popular culture and media histories of recurring tropes about media's powers and impact (Acland, 2012; Boddy, 2004; Sconce, 2000), and interrogated established narratives of newness and maturity (Gitelman, 2006; Jenkins, 2006; Marvin, 1988). However, the necessity to interrogate how storytelling works and the particular role of narration in informing the perception and use of technologies has been largely overlooked. Crucially, theories in literary and critical studies that examine narratives and anecdotes as cultural constructs with the capacity to enter into everyday life and experience (e.g. Cavarero, 2000; Olney, 1972) have not been taken into consideration. Thus, the notion of the biographies of media contributes to fill an important gap within literature on media and the imagination, stressing the importance to study narratives about media and to locate them within the broader contexts of media imaginaries and cultures. It shows that the power of storytelling to instantiate cultural meanings through a tale that is easily remembered, retold, and disseminated, concerns media as much as persons, things, and cultural objects.

Scholars in history of technology have interrogated the role of storytelling in the construction and consolidation of technologies' histories. Notably, John M. Staubenmaier reviewed different narratives of technological development through a textual analysis of articles published across several decades in the journal Technology \& Culture (Staudenmaier, 1984; see also Staudenmaier, 2002). Yet, being limited to scholarly narratives, his work provides little ground for examining how narratives enter into the way technologies are discussed in the broader public sphere and in popular culture. More recently, historians of technology have addressed 
technological successes and failures as narrative constructions rather than as qualities inherent to the technologies themselves (Edgerton, 2007; Gooday, 1998; Lipartito, 2003). Historians of media and technology working within the SCOT (Social Construction Of Technology) framework, moreover, have interrogated how imaginary and discursive constructions play a role in the initial phase of uncertainty or "interpretative flexibility," when a new technology is malleable and open to different and sometimes alternative interpretations or uses (see Pinch \& Bijker, 1987). With regard to this, employing the notion of biography shifts the focus on the question of how narrative patterns provide ways to insert technology within familiar trajectories conveyed in the form of anecdotes and stories. Biographies are a highly formalized literary genre whose use of anecdotal patterns to convey meaning has been the subject of intensive scrutiny by literary scholars and cultural historians (Benton, 2009, p. e.g.; Furbank, 2000; Kris \& Kurz, 1979). The notion of biography, therefore, provides both a powerful metaphor and a useful theoretical tool to question narrative patterns through which trajectories of media's histories are represented and imagined.

Biological and experiential events such as birth, maturity, aging, and death often enter in narrative constructions through which we attempt to make sense of media change (Acland, 2007; Ballatore \& Natale, 2015; Gaudreault \& Marion, 2005). Moreover, media historians have sometimes tended to conflate the actual biographies of living humans, such as inventors, with the technologies they became most closely associated with (e.g. Wu, 2011). Yet, Bruno Latour has criticized the tendency to attribute human agency and intention to technologies. He contends that scholars interested in science and technology should consider agency without the baggage associated with human intentionality (Latour, 2005). By employing the notion of biography, this article does not intend to reproduce the dynamics criticized by Latour; on the contrary, it 
employs the means of cultural critique and literary theory to interrogate why the stories we create and disseminate about technology bear resemblance with narratives unfolding individuals' lives.

As David Hendy (2012) recently recalled, the examination of the biographies of media professionals (at times also called "media biographies") can broaden the scope of media history by contributing subjective angles to its dominant narratives. His remarks stimulates us to question what remains of biographies if we take out the human persona, the human life upon which a story is constructed. Yet, as I aim to show, the analogy with the life stories of individuals provides relevance and meaning to the notion of biographies of media, encouraging us to scrutinize how media become characters within particular historical narratives. Storytelling, as Adriana Cavarero (2000) shows, proceeds through directions whose essential configuration are embedded in the storyteller's life. As a consequence, the lifecycle of individuals has provided exceedingly influential narrative patterns to recount and imagine the progression of media's histories. It is telling, in this regard, that biographic accounts of inventors and media pioneers so often conflate into narratives about the birth and development of media. To give one instance, in a popular memoir published by Tim Berners Lee, widely considered the main inventor of the World Wide Web, his life story becomes virtually indistinguishable from the story of how the Web was born. In the text, the association between the biographical account of the Web and its inventor sometimes emerges in illuminating ways: as Berners Lee describes the creation of the first Web browser/editor, he links the episode to the birth of his first child, noting that "as amazing as it would be to see the Web develop, it would never compare to seeing the development of our child" (Berners-Lee, 1999, p. 33). Another example can be found in the narratives about the development of new inventions being made in a garage, which have become 
entangled in the life stories of many entrepreneurs, as well as in the biographies of media such as the personal computer (Godelier, 2007).

The analogy between biographies of individuals and the biographies of media also concerns the subjective character of such narratives. In fact, the individual nature of biographical narratives shall encourage media scholars to address and unveil the "multiple layers" (Caine, 2010 , p. 2) through which media are inscribed in historical change and experience. This is the reason why it is important to talk about "biographies" of media rather than about a single biography referred to any given medium. One of the main aspects characterizing the stories we tell about media and technologies is their plurality: the coexistence of different and sometimes contrasting versions of how a medium was born, developed, became ubiquitous, or disappeared. Examples abound in the history of media. Jonathan Sterne, for instance, discusses two conflicting anecdotes about the reasons why the compact disk's length was established at seventy-four minutes. The first tale has the president of Sony, Norio Ohga, requesting that he wanted the CD to be as long as it was needed in order to play Beethoven's Ninth Symphony without interruption. The second tale has the executives of Philips wanting the CD to be about the same size as the compact cassette tape, in order to be easily transported (Sterne, 2012, p. 14). Examining the biographies of media entails the recognition that not a single narrative, but a complex web of narratives constitutes the core of each and every historical media culture.

\section{The Stories We Tell: Storytelling, Experience, Everyday Life}

Walter Benjamin distinguishes between information and storytelling, suggesting that while information lays claims to prompt verifiability, storytelling does not need to convey the essence of the thing, creating a more open narrative that sticks into memory and integrate with the 
reader's own experiences (Benjamin, 1968, pp. 83-110; see Stevenson, 2014). Like the stories to which Benjamin refers, biographies of media are not mere reports of events; they are recurring and highly standardized tales that appeal to our taste for narration and remain in our memory with an effectiveness that perhaps only storytelling allows.

Literary studies addressing the status of anecdotal biographies as a narrative form provide us with the most fitting means to comprehend how narratives about media signify and produce meaning. In biographies and autobiographies, a literary genre which became increasingly popular throughout the nineteenth and twentieth century (Lowenthal, 2006; Turley, 1993; Whalen, 2000), anecdotes have a twofold role. On the first hand, they add to the narrative character of the genre, which despite being non-fictional is based on narration and storytelling (Batchelor, 1995; Benton, 2009; Furbank, 2000). On the second hand, they contribute to enforce certain claims about the person who is the subject of the biographical sketch; they embody, in other words, certain representations of the person's character, e.g. her temperament, personality, and skills (Ortoleva, 1996). To make an example, in the autobiography of P.T. Barnum, a pioneer for the American entertainment industry, the anecdotes about the practical jokes conceived and made into practice by the protagonist contribute to enforce the representation of Barnum as the "prince of humbugs" (Adams, 1997; Cook, 2001; Harris, 1981). More broadly, anecdotes also entail certain representations of broader notions related to the character's profession and agency. In biographies of artists, for instance, anecdotes may support certain claims about the act of artistic creation, or confirm well-established imaginations about the "artistic" temperament (Kris \& Kurz, 1979); in biographies of inventors, they carry established representations of the act of invention and, more generally, the process of innovation (Godelier, 2007; Ortoleva, 1996); and so forth. 
As anecdotes in biographies carry certain representations of classes of individuals, anecdotes and stories about media contribute to how technologies and practices are represented and imagined within the public sphere, ultimately constructing something similar to "biographic accounts" of particular media. Alan Liu argues that the introduction of a new medium kindles a complex chain of reactions in our social and cultural world, which are channelled symbolically through what he calls "narratives of media encounter" (Liu, 2007). Examples of such narratives include reports about reactions of non-Western people to the introduction of new technologies, mentioned in some classic works for the field of media studies (McLuhan, 1964; Sontag, 1990); the myth of the gift of writing from the Egyptian god Theuth in Plato's Phaedrus (Plato, 2011); or the anecdote reported by French photographer Felix Nadar about Honoré de Balzac's reaction to photography as a "magical" technology (Nadar, 1994). "No new media experience is fully imaginable," Liu notes, "without the help of what may loosely be called narratives of new media encounter (...). Whether told from the perspective of the native of old media or the ambassador of new media, such tales are a staple of epochs undergoing media change” (Liu, 2007, p. 4).

An important characteristic of these stories is their recurrence. Take, for instance, two stories that have become veritable "founding myths" for cinema and radio broadcasting: the anecdote about the first spectators of the cinematograph panicking before the moving image of a train (often labelled "the train effect"), and the anecdote about the reaction of listeners to Orson Welles' "War of the Worlds" radio broadcast, who reportedly panicked at what they thought were actual news reports about the invasion of Martians. As historians of film and broadcasting have demonstrated, both anecdotes are apocryphal, or at least greatly exaggerated; yet, they became a veritable emblem for film's and broadcasting's early history, providing powerful narratives to represent their nature and their role in our society and helping consistently to 
structure early claims about media effects (Bottomore, 1999; Loiperdinger, 2004; Pooley \& Socolow, 2013a). The two tales mirror established patterns by which encounters with new technologies and media forms have been told and imagined throughout history. Stories of panicking audiences, in fact, proliferate since at least the nineteenth century, when they underlined the manipulative character of novel practices and media such as stage magic, freak shows, and photography (Dinius, 2012, pp. 32-38; Gunning, 1989b, p. 4; Halttunen, 1982, p. 3; Leeder, 2010). Similarly, reports about reactions to War of the Worlds emphasized the position of inexperienced spectators (Cantril, 1940). Thus, the two anecdotes stage the encounter between the old and the new. Through an established narrative pattern, they provide a way to imagine symbolically the transformations in the socio-cultural order resulting from media change (Liu, 2007 , p. 5)..$^{2}$

To return to the comparison with the biographical genre, James Olney famously argues that autobiographies are "metaphors of the self," since they provide ways to understand a wholly new experience by creating a relation with an experience already placed, ordered, and incorporated. Likewise, narratives of new media encounters are also metaphors that provide "something known and of our making, or at least at our choosing, that we put stand for, and so to help us understand, something unknown and not of our making” (Olney, 1972, p. 30). Their recurrence is not only symptomatic of the endurance throughout history of particular cultural understandings about media, but also of our necessity to relate the impact of new technologies to something already known. By following established narrative patterns, telling a story that, with little or no variations, has been recounted before (Fulton, 2005, pp. 6-8), anecdotal narratives help to preserve the consequentiality of our everyday life against the instability of technological change (Striphas, 2009, p. 10). 
One of the characteristics of storytelling is its capacity to activate the movement of imagination and the construction of meaning (Erami, 2015). Approaches to storytelling in disciplines such as philosophy (Cavarero, 2000), anthropology (Mattingly \& Garro, 2000; Stevenson, 2014), as well as media studies (Fulton, 2005) have compellingly showed how narrative is a fundamental way to give meaning to experiences and events. Employing the notion to the biographies of media has the potential to show the extent to which this applies to media history, too.

\section{The Power of Anecdotes: Narratives, Ideology, Power}

Despite the fact that biographies of media may refer to a distant or near past, they have an important impact on the present. Technologies function not only through their material substance, but also according to the narratives they generate or into which they are forced. As historian of technology David Edgerton (2007, pp. 17-18) points out, for instance, V2 rockets that were developed and built for use by the German army during WWII were ineffective in terms of resources deployed, effects and strategy. Yet, they were useful in order to keep alive the hopes of victory; in other words, they were weapons functioning primarily on a narrative rather than on a material level. Similarly, biographies of media are narratives with tangible effects, too. They have important consequences on how media enter into our life and experience, and how we imagine, prepare and construct our futures.

The example of narratives about the "death" of media is particularly apt to clarify how biographies of media provide tools that help to cope with the impact of media change in our everyday experience. The idea that an "old" medium might disappear as a consequence to the introduction of a new one is among the most frequently recurring narratives in media history. 
When television was introduced in the 1940s-1950s, for instance, fears aroused that it might cause the "death" of radio and cinema; similarly, the recent introduction of e-readers made many worry about the possibility of a world without paper and print books. History shows that such predictions are usually wrong (Chivers Yochim \& Biddinger, 2008; Edgerton, 2007; Gitelman, 2006). Old media may find new applications and contexts of use, rather than disappear: radio, for one, is still among the main sources of information and entertainment, notwithstanding the recurrence of predictions about its upcoming demise.

Why do narratives about the death of media, despite their failure to describe the actual dynamics of media change, continue to characterize biographies of media and, more broadly, our perception and representation of the dynamics through which new media are introduced and older media change? As argued elsewhere (Ballatore \& Natale, 2015), what made the narrative of the death of media so persistent is that they provide us with a familiar pattern to describe and domesticate the transformations brought by the introduction of new media in our everyday life and experience. It is important to consider that the introduction of new media - such as, for instance, smart phones and e-readers in our time, or television in the 1950s- challenge established habits and expectations in our everyday life (Kitchin \& Dodge, 2011). The everyday is what can be counted on, what provides the necessary stability to cope with experiences and more in general with our social life; it follows that we need cognitive and emotional strategies to cope with these changes (Striphas, 2009, p. 11). One of these strategies is the use of familiar narrative patterns, which, as Helen Fulton $(2005$, p. 7) points out, people often employ to make sense of new experiences and events. The tale of the disappearance or "death" of a medium, for instance, draws from a well-established narrative trope of Western culture: the assumption that each epoch is shaped by the end of what came before and the start of something new (Kermode, 
2000). It replicates symbolically the most basic biographic trajectory of a person's life, from birth to death - one of the most essential narrative patterns (Olney, 1972). As a result, the idea of the disappearance of the old medium responds well to the necessity of domesticating the impact of media change in our experience and everyday life (Lesage, 2013).

The impact of anecdotal narratives about media in our everyday life and experience has important implications related to issues of ideology and power, too. Narratives about obsolescence and newness are not only a strategy through which we domesticate media change and through which we cope with its emotional impact in our everyday life; they are also the carriers of particular ideological functions, and may be produced and employed to support particular social, economic and political agendas. To take again the example of the two competing narratives around the reasons why the compact disk's length was established at seventy-four minutes, Jonathan Sterne notes that

"The issue here is not just that one (likely somewhat mythologized) story has been circulating in place of another but that the two stories serve very different ideological functions. The Beethoven's Ninth Story authorized the CD as a format fit for high culture, thereby replaying a legitimation tactic used in the service of earlier recording formats (...). The second story is a tale of mediality, in which one format references extant practices in its design and conception, and in which the design of media involves industrial and cultural politics, as when television tried to mimic cinematic projection with a 4:3 aspect ratio." (Sterne, 2012, p. 14) 
Similar narratives, as Sterne observe, might be used to support particular visions of a technology, and the economic and strategic visions that are linked to it.

The narratives about the death of media provide a further example of how biographies of media enter into the discourse of political and social movements, which may profit from the ubiquity and the prominence of such narratives. An interesting case in this regard is the FiveStar-Movement (M5S), founded by comedian Beppe Grillo and web entrepreneur Gianroberto Casaleggio in Italy, which aroused to the status of second largest party at the national elections in 2013. The movement succeeded to place the narrative of media obsolescence and newness at the very core of its political message, associating itself with new media and the web. In their public messages, the leaders of the party represented themselves as the carriers of a new potential for democracy and change, based on the alleged power of the Web to shape a new public arena and forum. Furthermore, they struggled to identify their political opponents with the "old" media of television and the press. Thus, in the political message of the M5S, the claim that old media are dead became indissoluble from the claim that the Italian establishment was likewise "dead," and that a political earthquake driven by the movement was going to supersede traditional parties. The recurring narratives according to which old media (in this case, television and the press) would "die" as a consequence of the introduction of new media (Internet and the Web) reinforces the promise of a new political order, based on the abrupt dismissal of what, according to the movement's rhetoric, belongs exclusively to the past (Natale \& Ballatore, 2014).

The case of the M5S shows that biographies of media are powerful narratives that may be employed to reach and mobilize a wide potential public of citizens and consumers. Unveiling the biographies of media helps therefore to gain insight not only into how media are entangled in particular narratives, and how these in turn influence their presence and reception. It also sheds 
light on how such different and competing narrative constructions are employed to the advantage of individuals and groups, with their own political, economic and social agendas. Pointing to the impact of discourses about the Internet in orienting policy, Susan Crawford has observed that what is meant by "the Internet" determines which actors' voices will be listened to, what arguments will be respected, and which goals will be considered legitimate (Crawford, 2007). This applies well to the biographies of media, which influence the behaviors of social actors, and contribute to trigger particular approaches and policies.

\section{The Tales We Believe: Authenticity, Fabrication, Symmetry}

An important consequence of the plurality of biographies of media - the fact, discussed above, that there is no single narrative about a given media or about media in general, but rather a variety of different narratives - is that some of them refer to events that might have never taken place, or at least not in the precise way through they are recounted. Let us take again, for instance, the example of the anecdotes about early cinema and radio's panicking audiences. As historians have convincingly documented, the anecdote of the "train effect" hardly reflects historical facts. Close examinations of primary sources from several national contexts (Bottomore, 1999; Gunning, 1989a; Loiperdinger, 2004; Sirois-Trahan, 2004; Tsivian, 1994) revealed that, if there was any panic at all, this did not take the form of a full-scale escape or retreat, but merely of a "drawing back" of some people in the audience before the image of a train - something which a contemporary viewer may perhaps have experienced in watching a spectacular scene of an action movie, or in experiencing for the first time the effects of highdefinition 3D cinema (Elsaesser, 2013). Also, several elements in the conditions of early cinematic screenings suggest that audiences would have not reacted in such a dramatic way. 
Watching a moving image was certainly an astounding experience for late-nineteenth-century audiences; it was still, however, a quite defective illusion which lacked of color and sound (Gaudreault, 2004; Gunning, 2000; Mennel, 2008, p. 4). Similarly, reports may have exaggerated the dimension of the panic arisen by the listening of Welles' War of the Worlds broadcast (Campbell, 2010, pp. 26-44). While social scientists and historians of radio and broadcasting have often contended that the panic had actually taken place (Cantril, 1940; Johnson \& Foote, 1993; Wolfe, 1980), Jefferson Pooley and Michael Socolow convincingly document that it contained, not unlike the train effects, strong elements of fabrication: "the supposed panic was so tiny as to be practically immeasurable on the night of the broadcast. (...) Almost nobody was fooled by Welles' broadcast” (Pooley \& Socolow, 2013b).

Whenever we deal with history, the opposition between fact and artifact is a key problem. Historians employ a wide array of methodologies for comparing and corroborating their sources, in order to establish if an event is a historical fact or rather a fabrication (Howell \& Prevenier, 2001). In journalism studies, a similar endeavor has animated the inquiry of scholars such as W. Joseph Campbell, who examined newspaper reports of the panic generated by the War of the Worlds broadcast alongside several other "media-driven myths," i.e. "dubious, fanciful, and apocryphal stories about or by the news media that are often retold and widely believed" (Campbell, 2010, p. 2). Yet, while Campbell's scrutiny has the merit of assessing the credibility of anecdotes, it does not consistently advance our understanding of how such stories inform our perception and imagination of the role of media in our societies. Additionally, as Campbell acknowledged, the cultural impact of anecdotal narratives may follow logics that are independent from their historical factuality or credibility. As he perceptively observed, his own debunking 
may have the indirect effect of perpetuating the myth, encouraging controversy and contributing to the incessant reemergence of the story (p. 5).

In contrast to such approaches, by underlining the narrative character of anecdotes, the notion of the biographies of media implies that we shall consider the question of authenticity as secondary. What is most relevant, in fact, is the extent and the way narratives reverberate in journalistic and historical reports about the new medium, becoming a kind of "myth" of the origins of cinema, broadcasting, or other media. From this perspective, as the authors of a classic study on popular anecdotes about artists observe, "the only significant factor is that an anecdote recurs, that it is recounted so frequently as to warrant the conclusion that it represents a typical image of the artist" (Kris \& Kurz, 1979, p. 11). As Charles Acland (2012) has shown in his examination of myths surrounding subliminal influence, stories that are not verifiable frequently shape vernacular representations of media and their role in our societies. Indeed, controversies may result in consolidating, rather than weakening, the cultural presence of an anecdote. This has often been the case in the history of media (Bartholomew \& Radford, 2012). The emergence of the popular press in nineteenth-century America, for instance, was accompanied by the discovery that debates about the authenticity of a story could arouse rather than discourage the interest of the public (Cook, 2001; Goodman, 2008; Lears, 1994).

Scholars interested in the biographies of media, therefore, should take an informed but to a certain extent also agnostic position towards the authenticity of anecdotes and narratives. Take, for instance, the anecdote of of Steve Jobs and Steve Wozniak assembling the first Apple computer in Jobs' garage. This myth has been challenged by one of the two protagonists of the story, Wozniak, who reported that the garage played a very marginal role in the events that brought to the realization of the first Apple computer (Audia \& Rider, 2005; Morozov, 2012). Of 
course, such controversy is relevant to the study of the biographies of the personal computer, since considerations about its authenticity may inform the way the anecdote is received and, to some extent, also the way it is told. Yet, if our aim is to comprehend how biographies of media contribute to shape their representation in the public sphere, the analysis should also go beyond the simple question if an anecdote is trustworthy or not. In fact, the anecdote has become a veritable founding myth for the technology of personal computers, reinforcing established representations of innovation and entrepreneurship and linking the development of modern computing with the agency of individuals who, despite limited access to technological and financial means, outdid giant corporations such as IBM (Godelier, 2007; Turner, 2006).

An interesting solution to the problem of authenticity in the biographies of media is the application of the principle of symmetry, as conceptualized within the history and sociology of science. Given the frequency with which scientific theories are challenged, disproved, or abandoned throughout history, historians of science constantly deal with a similar dilemma. The older solution was that deviations from the straight path of reason could be explained socially, but they could not be treated equally, for truth has to be considered self-explanatory. In contrast to this, David Bloor proposed that the sociology of scientific knowledge should be symmetrical. The same types of causes should explain, therefore, "true" as well as "false" beliefs (Bloor, 1976). The advantage of employing this principle, as Bruno Latour underlines, concerns the study of the failures as well as the study of those theories and models that have stood the trial of history: "when the balance of symmetry is reestablished with precision, the discrepancy that allows us to understand why some win and others lose stands out all the more sharply" (Latour, 1993, p. 94). 
Applying the principle of symmetry to the study of the biographies of media has important consequences. In a given historical moment the two versions of a story -that the Apple computer, for instance, was and was not created in Jobs' garage- may exist at the same time; however, they will be narrated by different agents, connected to different representations, and used to support different agendas. The question if an anecdote is based on true events or if it is a historical fabrication is important and should be taken into account; however, we should not forget that narratives exist and are meaningful regardless of their authenticity.

Interestingly, media scholars Vincent Mosco (2004) and Peppino Ortoleva (2009) reach similar conclusions when they address the issue of authenticity with regard to technological myths. As Mosco points out, "The key point to keep in mind is that (...) myths are neither true nor false, but living or dead. A myth is alive if it continues to give meaning to human life, if it continues to represent some important part of the collective mentality of a given age, and if it continues to render socially and intellectually tolerable what would otherwise be experienced as incoherence" (29). Similarly, Ted Striphas contends that by "myth" he does not intend "a falsehood but rather a particularly generative type of communication that trades on common sense" (Striphas, 2009, p. 6). Tung-Hui Hu's recent study of how the metaphor of the cloud became one of the leading ways to describe the functioning and the structure of the Internet provides a very apt example of how well this applies to biographies of media. Hu shows that the idea that the structure of the Internet network originated in the attempt to respond to a potential nuclear attack is historically wrong; yet, this myth of origins is kept alive despite evidence of the contrary. Ultimately, he notes, debunking the myth is less crucial than comprehending the reason why the story persists in digital culture $(\mathrm{Hu}, 2015)$. 
Whether an anecdote is based or not on events that have actually taken place, its social and cultural presence depends on the extent to which the anecdote is reported, disseminated, and used by different agents, such as individuals and institutions. Studying the biographies of media passes through the unveiling of how narratives are embedded in complex webs of agencies and agendas. It underlines how authenticity and fakery are socially and culturally determined, rather than being a fixed quality inherent to certain anecdotes and stories. This is only possible if we adopt a symmetrical perspective, which gives emphasis to all elements that concur to the representation of media in the public sphere.

\section{Conclusion: Towards a Transmedia History}

This article proposes the study of the biographies of media, broadly defined as the bodies of narratives unfolding and representing the lifespans of different media. Turning particular representations of media into storytelling, anecdotal narratives such as the ones examined here contribute to the construction of biographies of media, which reverberate in popular and historical reports. By employing examples from the history of cinema, radio broadcasting, the compact disc, the personal computer and the Web, the article also calls for the necessity of integrated approaches that go beyond established disciplinary boundaries and move across different media and practices (Natale, 2012b; Müller, 2000; Nead, 2007).

Moving toward such approaches is crucial if we consider the extent to which narratives about media are frequently addressed within the history of a single medium or technology, rather than within the context of broader media histories. Scholars addressing the anecdote of cinema's panicking audience, for instance, have mainly worked on its significance within the history of the cinematic medium (Bottomore, 1999; Loiperdinger, 2004; Sirois-Trahan, 2004). In my brief 
examination of this case, I have employed a different perspective, pointing to the recurrence of anecdotes about panicking audiences within several contexts and in reference to different media. Employing a similar approach has two main advantages. First, it helps to better contextualise biographies of particular media and, therefore, to advance our understanding of their meaning and implications. Second, it sheds light on the way anecdotes as a narrative form contribute to the insertion of representations of media in our social world and everyday life. From this viewpoint, examining recurrent narratives in the biographies of media opens up to relevant questions about how media are connected to particular forms of the social and cultural imaginary.

While the notion of biography might seem to suggest that media have a specific and univocal lifespan, and therefore can be considered in isolation from each other, it is important to reiterate that the notion of the biographies of media refers to how media histories are told. It does not aim to construct a narrative about media history, or to propose a privileged narrative before the others. As noted above, the use of the plural form of "biographies" is meant to underline the plurality and heterogeneity of narrative recollections about media, which is a fundamental assumption for every approach to discourses about technology and media. A medium like the Internet, for instance, is thought of differently and contextualized differently in everyday life by different social actors and groups around the world. The emergence of diverse and sometimes contrasting narratives may have important consequences in shaping the behavior of social groups and in orienting public discussions and policies about this medium.

In conclusion, the notion of the biographies of media provides a theoretical framework that can be applied to historical and contemporary approaches within media studies and related disciplines. Scholars of media should address biographies of media as highly structured 
narratives that shed light on how media are thought, imagined, and represented. This entails working in two different directions: on the one hand, identifying the different historical and anecdotal narratives through which the emergence and development of media are retold, and searching for the underlying layers of meaning and ideology embedded in them; and on the other hand, looking at the contexts where these stories are reported and circulated, interrogating to what extent they serve the purpose of specific groups interested in a particularly interpretation of the medium's technological and social role. In fact, to comprehend their significance and consequence for our perception of media, one needs to unveil the peculiarities and the links that distinguish and unify different anecdotes and stories, as well as the networks of agents and institutions that contribute to their creation and dissemination. 


\section{References}

Acland, Charles R. (2012). Swift viewing: The popular life of subliminal influence. Durham: Duke University Press.

Acland, Charles R. (Ed.). (2007). Residual media. Minneapolis: University of Minnesota Press. Adams, Bluford. (1997). E pluribus Barnum: The great showman and the making of U.S. popular culture. Minneapolis: University of Minnesota Press.

Appadurai, Arjun. (1986). The social life of things: Commodities in cultural perspective. Cambridge: Cambridge University Press.

Ballatore, A., \& Natale, S. (2015). E-readers and the death of the book: Or, new media and the myth of the disappearing medium. New Media \& Society. Published online before print May 18, 2015. DOI: $10.1177 / 1461444815586984$

Bartholomew, Robert E., \& Radford, Benjamin. (2012). The Martians have landed!: A history of media-driven panics and hoaxes. Jefferson, N.C.: McFarland.

Batchelor, John (Ed.). (1995). The art of literary biography. Oxford: Clarendon Press.

Benjamin, Walter. (1968). Illuminations. New York: Schocken Books.

Benton, Michael. (2009). Literary biography: An introduction. Malden, MA: Wiley-Blackwell. Berners-Lee, Tim. (1999). Weaving the Web: The Past, Present and Future of the World Wide Web by its Inventor. London: Orion Business.

Bloor, David. (1976). Knowledge and social imagery. London: Routledge.

Boddy, William. (2004). New media and popular imagination: Launching radio, television, and digital media in the United States. Oxford: Oxford University Press.

Bottomore, Stephen. (1999). The panicking audience?: Early cinema and the 'train effect'. Historical Journal of Film, Radio and Television, 19(2), 177-216. 
Caine, Barbara. (2010). Biography and History. Basingstoke, UK: Palgrave Macmillan.

Campbell, W. Joseph. (2010). Getting it wrong: Ten of the greatest misreported stories in American journalism. Berkeley: University of California Press.

Cantril, Hadley. (1940). The invasion from Mars: A study in the psychology of panic. Princeton: Princeton University Press.

Carey, James W. (1989). Communication as culture: Essays on media and society. Boston: Unwin Hyman.

Cavarero, Adriana. (2000). Relating narratives: Storytelling and selfhood. London New York: Routledge.

Chivers Yochim, Emily, \& Biddinger, Megan. (2008). 'It kind of gives you that vintage feel': vinyl records and the trope of death. Media, Culture \& Society, 30(2), 183-195. DOI: $10.1177 / 0163443707086860$

Cook, James W. (2001). The arts of deception: Playing with fraud in the age of Barnum. Cambridge: Harvard University Press.

Crawford, Susan. (2007). Internet Think. Journal on Telecommunications and High Technology Law, 5, 467-486.

Daston, Lorraine (Ed.). (2000). Biographies of scientific objects. Chicago: University of Chicago Press.

Dinius, Marcy J. (2012). The camera and the press: American visual and print culture in the age of the daguerreotype. Philadelphia, Pa.: University of Pennsylvania Press.

Edgerton, David. (2007). Shock of the old: Technology and global history since 1900. Oxford: Oxford University Press. 
Edwards, Elizabeth. (2002). Material beings: Objecthood and ethnographic photographs. Visual Studies, 17(1), 67-75.

Elsaesser, Thomas. (2013). The "return" of 3-D: On some of the logics and genealogies of the image in the twenty-first century. Critical Inquiry, 39(1), 217-246.

Erami, Narges. (2015). Of ladders and looms: Moving through Walter Benjamin's 'Storyteller'. Anthropological Theory, 15(1), 92-105. DOI: 10.1177/1463499614564015

Flichy, Patrice. (2007). The Internet Imaginaire. Cambridge, Mass.: MIT Press.

Fulton, Helen. (2005). Narrative and media. Cambridge: Cambridge University Press.

Furbank, P.N. (2000). The craftlike nature of biography. In J. Law \& L. K. Hughes (Eds.), Biographical passages: Essays in Victorian and Modernist biography (pp. 18-27). Columbia: University of Missouri Press.

Gaudreault, André. (2004). Il cinema delle origini o della cinematografia-attrazione. Milano: Il Castoro.

Gaudreault, André, \& Marion, Philippe. (2005). A medium is always born twice. Early Popular Visual Culture, 3(1), 3-15. DOI: 10.1080/17460650500056964

Gell, Alfred. (1998). Art and agency: An anthropological theory. Oxford: Clarendon Press.

Gitelman, Lisa. (2006). Always already new: Media, history and the data of culture. Cambridge, Mass.: MIT Press.

Godelier, Eric. (2007). “Do you have a garage?” Discussion of some myths about entrepreneurship. Business and Economic History Online, 5, 1-20.

Gooday, Graeme. (1998). Re-writing the 'book of blots': Critical reflections on histories of technological 'failure'. History and Technology, 14(4), 265-291. DOI: $10.1080 / 07341519808581934$ 
Goodman, Matthew. (2008). The Sun and the moon: The remarkable true account of hoaxers, showmen, dueling journalists, and lunar man-bats in nineteenth-century New York. New York: Basics Books.

Gunning, Tom. (1989a). An aesthetic of astonishment: Early film and the (in)credulous spectator. Art and Text, 34, 31-45.

Gunning, Tom. (1989b). 'Primitive' cinema: A frame-up? Or the trick's on us. Cinema Journal, $28(2), 3-12$.

Gunning, Tom. (2000). The cinema of attraction: Early cinema, its spectator, and the avantgarde. In R. Stam \& T. Miller (Eds.), Film and theory: An anthology (pp. 229-235). Malden: Blackwell.

Halttunen, Karen. (1982). Confidence men and painted women: A study of middle-class culture in America, 1830-1870. New Haven: Yale University Press.

Harris, Neil. (1981). Humbug: The art of P.T. Barnum. Chicago, Ill.: University of Chicago Press.

Hendy, David. (2012). Biography and the emotions as a missing 'narrative' in media history: A case study of Lance Sieveking and the early BBC. Media History, 18(3-4), 361-378.

Howell, M.C., \& Prevenier, W. (2001). From reliable sources: An introduction to historical methods. Ithaca: Cornell University Press.

Hu, Tung-Hui. (2015). A prehistory of the cloud. Cambridge, Mass.: MIT Press.

Huhtamo, Erkki. (1997). From kaleidoscomaniac to cybernerd: Notes toward an archaeology of the media. Leonardo, 30(3), 221-224.

Huhtamo, Erkki. (2008). Cyborg Is a Topos. In D. Bulatov (Ed.), Evolution Haute Couture: Art and Science in the Post-Biological Age. Part 2 (pp. 259-269). Kaliningrad: BB NCCA. 
Huhtamo, Erkki. (2013). Illusions in motion: Media archaeology of the moving panorama and related spectacles. Cambridge, Mass.: MIT Press.

Jenkins, Henry. (2006). Convergence culture: Where old and new media collide. New York: New York University Press.

Johnson, Phylis, \& Foote, Joe S. (1993). Pranks and policy: Martians, nuclear bombs and the 1992 ruling on broadcast hoaxes. Journal of Radio Studies, 2(1), 69-87. DOI:

$10.1080 / 19376529309384509$

Kermode, Frank. (2000). The sense of an ending: Studies in the theory of fiction. Oxford: Oxford University Press.

Kitchin, Rob, \& Dodge, Martin. (2011). Code/space : Software and everyday life. Cambridge, Mass.: MIT Press.

Kluitenberg, Eric (Ed.). (2006). Book of imaginary media: Excavating the dream of the ultimate communication medium. Rotterdam: NAI.

Kopytoff, Igor. (1986). The cultural biography of things: Commoditization as process. In A. Appadurai (Ed.), The social life of things: Commodities in cultural perspective (pp. 6491). Cambridge: Cambridge University Press.

Kris, Ernst, \& Kurz, Otto. (1979). Legend, myth, and magic in the image of the artist: A historical experiment. New Haven: Yale University Press.

Latour, Bruno. (1993). We have never been modern. Cambridge, Mass.: Harvard University Press.

Latour, Bruno. (2005). Reassembling the social: An introduction to actor-network-theory. Oxford: Oxford University Press. 
Lears, T. J. Jackson. (1994). Fables of abundance: A cultural history of advertising in America. New York: Basic Books.

Leeder, Murray. (2010). M. Robert-Houdin goes to Algeria: Spectatorship and panic in illusion and early cinema. Early Popular Visual Culture, 8(2), 209-225.

Lesage, Frédérik. (2013). Cultural biographies and excavations of media: Context and process. Journal of Broadcasting \& Electronic Media, 57(1), 81-96. DOI:

$10.1080 / 08838151.2012 .761704$

Lesage, Frédérik. (2016). A cultural biography of application software. In C. Paterson, D. Lee, \& A. Saha (Eds.), Advancing media production research: Shifting sites, methods, and politics (pp. 217-232). Basingstoke, UK: Palgrave Macmillan.

Lipartito, Kenneth. (2003). Picturephone and the information Age: The social meaning of failure. Technology and Culture, 44(1), 50-81.

Liu, Alan. (2007). Imagining the new media encounter. In R. G. Siemens \& S. Schreibman (Eds.), A companion to digital literary studies (pp. 3-25). Malden, MA: Blackwell Pub. Loiperdinger, Martin. (2004). Lumière's arrival of the train: Cinema's founding myth. The Moving Image, 4(1), 89-118.

Lowenthal, Leo. (2006). The triumph of mass idols. In P. D. Marshall (Ed.), The celebrity culture reader (pp. 124-152). New York: Routledge.

Marvin, Carolyn. (1988). When Old Technologies Were New: Thinking about Electric Communication in the Late Nineteenth Century. New York: Oxford University Press. Marx, Leo. (1964). The Machine in the Garden: Technology and the Pastoral Ideal in America. New York: Oxford University Press. 
Mattingly, Cheryl, \& Garro, Linda C. (2000). Narrative and the cultural construction of illness and healing. Berkeley: University of California Press.

McLuhan, Marshall. (1964). Understanding media: The extensions of man. Toronto: McGrawHill.

Mennel, Barbara Caroline. (2008). Cities and cinema. London: Routledge.

Mosco, Vincent. (2004). The digital sublime: Myth, power, and cyberspace. Cambridge, Mass.: MIT Press.

Müller, Jürgen E. (2000). L’intermédialité, une nouvelle approche interdisciplinaire : perspectives théoriques et pratiques à l'exemple de la vision de la télévision. Cinémas, 10(2-3), 105-134.

Nadar, Félix. (1994). Quand j'étais photographe. Paris: Seuil.

Natale, S. (2012a). Fantasie mediali: Storia dei media e la sfida dell'immaginario. Studi Culturali, 9(2), 269-284. DOI: 10.1405/38079

Natale, S. (2012b). Photography and Communication Media in the Nineteenth Century. History of Photography, 36(4), 451-456. DOI: 10.1080/03087298.2012.680306

Natale, S., \& Balbi, G. (2014). Media and the imaginary in history: The role of the fantastic in different stages of media change. Media History, 20(2), 203-218. DOI: $10.1080 / 13688804.2014 .898904$

Natale, S., \& Ballatore, a. (2014). The web will kill them all: new media, digital utopia, and political struggle in the Italian 5-Star Movement. Media, Culture \& Society, 36(1), 105121. DOI: $10.1177 / 0163443713511902$

Nead, Lynda. (2007). The haunted gallery: Painting, photography, film c.1900. New Haven: Yale University Press. 
Nye, David E. (1994). American Technological Sublime. Cambridge, Mass.: MIT Press.

Olney, James. (1972). Metaphors of self: The meaning of autobiography. Princeton, N.J.:

Princeton University Press.

Ortoleva, Peppino. (1996). Vite geniali: Sulle biografie aneddotiche degli inventori. Intersezioni, $1,41-61$.

Ortoleva, Peppino. (2009). Modern mythologies, the media and the social presence of technology. Observatorio (OBS) Journal, 3(1), 1-12.

Pinch, Trevor J., \& Bijker, Wiebe E. (1987). The social construction of facts and artifacts: Or how the sociology of science and the sociology of technology might benefit from each other. In W. E. Bijker, T. P. Hughes \& T. J. Pinch (Eds.), The social construction of technological systems: New directions in the sociology and history of technology (pp. 1750). Cambridge, Mass.: The MIT Press.

Plato. (2011). Phaedrus. Cambridge: Cambridge University Press.

Pooley, Jefferson, \& Socolow, Michael J. (2013a). Checking up on The Invasion from Mars: Hadley Cantril, Paul Lazarsfeld, and the making of a misremembered classic. International Journal of Communication, 7, 1920-1948.

Pooley, Jefferson, \& Socolow, Michael J. (2013b). The myth of the War of the Worlds panic. Retrieved from http://www.slate.com/articles/arts/history/2013/10/orson welles war of the worlds pan ic myth the infamous radio broadcast did.html

Sconce, Jeffrey. (2000). Haunted media: Electronic presence from telegraphy to television. Durham: Duke University Press. 
Silverstone, R., \& Haddon, L. (1996). Design and the domestication of information and communication technologies: Technical change and everyday life. In R. Mansell \& R. Silverston (Eds.), Communication by design: The politics of information and communication technologies (pp. 44-74).

Sirois-Trahan, Jean-Pierre. (2004). Mythes et limites du train-qui-fonce-sur-les-spectateurs. In V. Innocenti \& V. Re (Eds.), Limina: Le soglie del film (pp. 203-216). Udine: Forum.

Sontag, Susan. (1990). On photography. New York: Anchor Books.

Staudenmaier, John M. (1984). Technology's storytellers: Reweaving the human fabric. Cambridge, Mass.: MIT Press.

Staudenmaier, John M. (2002). Rationality, agency, contingency: Recent trends in the history of technology. Reviews in American History, 30(1), 168-181.

Sterne, Jonathan. (2012). MP3: The meaning of a format. Durham: Duke University Press.

Stevenson, Lisa. (2014). Life beside itself: Imagining care in the Canadian Arctic. Berkeley, Calif.: University of California Press.

Striphas, Theodore G. (2009). The late age of print: Everyday book culture from consumerism to control. New York: Columbia University Press.

Thibault, Ghislain. (2013). The Automatization of Nikola Tesla: Thinking Invention in the Late Nineteenth Century. Configurations, 21(1), 27-52.

Tsivian, Yuri. (1994). Early cinema in Russia and its cultural reception. London: Routledge.

Turley, David (1993). A usable life: representations of Abraham Lincoln. In D. Ellis (Ed.), Imitating art: essays on biography (pp. 53-66). London: Pluto.

Whalen, Terence. (2000). Introduction. In P. T. Barnum (Ed.), The Life of P. T. Barnum, Written by Himself (pp. vii-xxxvii). Urbana: University of Illinois Press. 
Wolfe, G. Joseph. (1980). 'War of the Worlds' and the editors. Journalism Quarterly, 57(1), 3944.

Wu, Tim. (2011). The master switch: The rise and fall of information empires. New York: Vintage Books.

\footnotetext{
${ }^{1}$ In a similar vein, historian of science Lorraine Daston reasons that "if humans have biographies, so have things; if artifacts can come into being, so should scientific objects" (Daston, 2000, p. 13).

${ }^{2}$ Erkki Huhtamo (1997) has proposed that the aim of media archaeology is to study topoi, i.e. those cyclical phenomena that emerge in different moments throughout media history, transcending specific historical contexts. He contends that "contemporary media culture is futuristic only in appearance. Underneath its surface it relies on tried-out formulas, or topoiundercover messengers of hidden continuities" (Huhtamo, 2008).
} 